\title{
Samba Diop, Discours nationaliste et identité ethnique à travers le roman sénégalais
}

\section{Ilaria Vitali}

\section{(2) OpenEdition}

1 Journals

\section{Edizione digitale}

URL: http://journals.openedition.org/studifrancesi/33903

DOI: 10.4000/studifrancesi.33903

ISSN: 2421-5856

\section{Editore}

Rosenberg \& Sellier

\section{Edizione cartacea}

Data di pubblicazione: 1 décembre 2005

Paginazione: 693

ISSN: 0039-2944

\section{Notizia bibliografica digitale}

Ilaria Vitali, «Samba Diop, Discours nationaliste et identité ethnique à travers le roman sénégalais», Studi Francesi [Online], 147 (XLX | III) | 2005, online dal 30 novembre 2015, consultato il 18 avril 2021. URL: http://journals.openedition.org/studifrancesi/33903; DOI: https://doi.org/10.4000/studifrancesi. 33903

Questo documento è stato generato automaticamente il 18 avril 2021.

\section{(c) $(1) \ominus$}

Studi Francesi è distribuita con Licenza Creative Commons Attribuzione - Non commerciale - Non opere derivate 4.0 Internazionale. 


\title{
Samba Diop, Discours nationaliste et identité ethnique à travers le roman sénégalais
}

\author{
Ilaria Vitali
}

\section{NOTIZIA}

SAMBA DIOP, Discours nationaliste et identité ethnique à travers le roman sénégalais, Paris,

L'Harmattan, 2003, pp. 180.

1 In questo brillante saggio, Samba Diop affronta i concetti di nazione, Stato-nazione, nazionalismo moderno, etnicità e métissage attraverso un'acuta analisi del romanzo senegalese d'espressione francese. Lo studio di Samba Diop, professore di letteratura e cinema francofono all'Università di Harvard, incomincia infatti dall'esame dei romanzi e dei racconti di alcuni tra i più importanti autori del Senegal, tra cui Ousmane Sembène, Aminata Saw Fall, Cheikh Hamidou Kane. Lo studio è poi impreziosito da una poesia dell'ugandese Heny Barlow, dall'eloquente titolo, Building the Nation, che getta una nuova luce sul concetto di nazione nell'Africa contemporanea postcoloniale. Di grande interesse anche la ricca bibliografia sui concetti di nazionalismo da un lato, métissage biologico-culturale dall'altro. Privilegiando l'approccio regionale e nazionale, il saggio si inserisce nella linea del rinnovamento della critica letteraria sul romanzo francofono africano. 